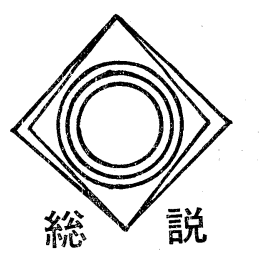

一般炭利用拡大とコールチェーン

の確立

\section{1 電力事業}

表 1 により電力向石炭荷渡実績の推移を見ると, 55 年7月より国内炭, 輸入炭共に顕著に増加し始め, 石 炭合計で90万トン/月 以上のペースで推移している。 これは，何よりも第二次石油危機を契機として石油の 価格の大幅な上昇と石油の供給制約が明確となった一 方, 54年末迄は石炭の価格は安定的に推移していたた め, 油炭格差が大きく拡大し $-10^{3} \mathrm{kcal}$ 当り単価で石 炭は重油の 40 ～ $50 \%$ (ハンドリングなどの石炭利用上 のデメリット $20 \%$ 含む）となる一，石炭利用のメリ ットが大きく増大したためである。電力業界において は, 石炭焚きとして設計, 建設されたが, その後石油焚 きに転換していた既設石油火力の石炭への再転換和よ び既設石炭火力に和ける石炭混焼率の引上げといら形 でまず石炭転換の動きが起ったと同時に，55年10月 1 日に運開した国内炭火力, 北海道電力の苫東厚真 1 号 機35万kW，拉よび56年 1 月 16 日に運開した最初の本 格的な輸入炭火力, 電源開発の松島 1 号機 50 万W $\mathrm{kW}$ おける試運転用および貯炭積増し用の石炭も，55年 7 月からの石炭利用の著しい増加に寄与しているものと 考えられる。
-1981.2 .4 受理一

日本エネルギー経済研究所 千 村 明

このような電力事業に和ける石炭転換への急速な動 きは，何よりも石炭火力の経済性上の優位が大きく高 まったことによるものであり, 表 2 にり発電コスト の比較を見ると, 石炭火力の発電コストは14.12円/ $\mathrm{kWh}$ (送電端以下同じ) と, 原子力の 11.45 円 $/ \mathrm{kWh}$ に次いで安い。従って, 電力業界としては経済性和よ び然料供給の安定性の面で最も優れている原子力を推 進するのが最善の道であるが，国民の間に“核アレル ギー”がきわめて強いためその立地は遅々として進ま ないのが現状であり，こらした原子力立地の遅れをか バーし，経済性と然料供給の面で制約がきわめて大き い重油火力に代わるものとして, 輸入炭火力の建設を 積極的に推進しているのが，電力業界の最近の状況で ある。

以上のような状況を踏まえて, 表 4 により電力に秝 ける石炭消費量の見通しはどのようになっているか見 ることとしたい。60年度については，既設分および施 設計画計上済の分を合わせて，出力で 1,011 万 $\mathrm{kW}$, 石炭消費量 1,615 万トンとなる。これに，石炭混焼率 アップおよび石炭転換による石炭消費増加量 715 万卜 ンの中時期の固まっているもの 238 万トンが 60 年度迄 の石炭消費量の増分として加わるが，一方で発電所の

表 1 電力向 石炭荷 渡 推 移

\begin{tabular}{|c|c|c|c|c|c|c|c|c|c|c|c|c|}
\hline & & & \multicolumn{3}{|c|}{54 年 度 } & \multirow{2}{*}{$\begin{array}{l}55 \text { 年度 } \\
\text { 上 期 }\end{array}$} & \multirow{2}{*}{ 54年10月 } & \multirow{2}{*}{ 11月 } & \multirow{2}{*}{ 12月 } & \multirow{2}{*}{ 55年 1 月 } & \multirow{2}{*}{2 月 } & \multirow{2}{*}{3 月 } \\
\hline & & & 上 期 & 下 期 & 計 & & & & & & & \\
\hline 国 & 内 & 炭 & 4,403 & 4,434 & 8,837 & 4,758 & 755 & 756 & 723 & 702 & 720 & 777 \\
\hline 輸 & 入 & 崖 & 130 & 111 & 241 & 428 & 30 & 19 & 30 & 12 & 19 & 1 \\
\hline 合 & & 計 & 4,533 & 4,545 & 9,078 & 5,186 & 785 & 775 & 753 & 714 & 739 & 778 \\
\hline
\end{tabular}

第二研究室 東京都港区虎ノ門1-18-1 
表 3 発電コスト比較の前提

\begin{tabular}{|c|c|c|c|c|}
\hline & 原子 力 & $\mathrm{L} N \mathrm{~N}$ 火力 & 重 油 火 力 & 石炭火力 \\
\hline ケース設定 & $\begin{array}{l}\text { 在来計算方式による } \\
\text { (除, デュミッショ } \\
\text { ニングコスト, 抽 } \\
\text { び低レベル放射性廃 } \\
\text { 棄物の数量コスト) }\end{array}$ & & $\begin{array}{l}\text { 脱硝 : } 50 \% \text { 装備 } \\
\text { 脱硫 : 装備せず } \\
\text { L.S. 重油にて対処 }\end{array}$ & $\left.\begin{array}{l}\text { 脱硫 } \\
\text { 脱硝 }\end{array}\right\} 100 \%$ 装備 \\
\hline 燃 料 価 格 & 表 & $\begin{array}{l}63,000 \text { 円 } \mathrm{T} \\
\left(\begin{array}{l}55 \text { 年 } 9 \text { 月 } \\
\mathrm{C} \text { I F 価格 }\end{array}\right) \\
\end{array}$ & 59,900 円 $/ \mathrm{k} \ell$ & $\begin{array}{l}13,000 \text { 円 } / \mathrm{T} \\
\left(\begin{array}{l}55 \text { 年 } 9 \text { 月 } \\
\mathrm{C} \text { I F 価格 }\end{array}\right) \\
\end{array}$ \\
\hline
\end{tabular}

核燃料サイクルの要素価格見通し

\begin{tabular}{|c|c|c|c|c|c|c|}
\hline $\begin{array}{c}\text { ウ } \\
\$ / l \mathrm{~b} \mathrm{U}_{3} \mathrm{O}_{8}\end{array}$ & $\begin{array}{l}\text { 精 鉱 } \\
\$ / \mathrm{kg} \mathrm{U} \mathrm{U}_{3} \mathrm{O}_{8}\end{array}$ & $\begin{array}{c}\text { 転 換 } \\
\$ / \mathrm{kg}-\mathrm{U}\end{array}$ & $\begin{array}{l}\text { 濃 縮 } \\
\$ / \mathrm{kg} \cdot \mathrm{swu}\end{array}$ & $\begin{array}{l}\text { 加 I } \\
\$ / \mathrm{kg}-U\end{array}$ & $\begin{array}{c}\text { 使用済燃料輸送 } \\
\$ / \mathrm{kg}-\mathrm{U}\end{array}$ & $\begin{array}{c}\text { 再 処 理 } \\
\$ / \mathrm{kg}-\mathrm{U}\end{array}$ \\
\hline 32 & 70 & 6 & 98 & 417 & 140 & 700 \\
\hline
\end{tabular}

（注）炉心期間は 4 年，転換，濃縮は初装荷の 2 年前，成型加工は，その 1 年前と想定した。また使用済 燃料を炉からとり出し輸送するまでの期間は 1 年, また再処理の終了時点までの期間は 2 年と想定 した。な物長期引き戻し率は $8 \%$ と想定した。主な炉特性データ

熱効率 : $33.2 \%$, 燃焼度 : $29,500 \mathrm{MWD} / \mathrm{t}$, 設備利用率 : $70 \%$, 初装荷量 : 10,855 トン

建設は計画より $2 \sim 3$ 年遅れるのが通例であり, 施設 計画計上済分の中から建設が計画より遅れるものが出 て来るものと考允られので, これが混焼率アップお よび転換期待分の 238 万トンと相殺されるものと想定 し，これは見通しの数值の染外とすることとした。 65 年度については，既設分叔よび施設計画計上済分の外 に，電力会社が60年代前半に運開を計画しているとし

(単位 : $1,000 \mathrm{M} . \mathrm{T}$. )

\begin{tabular}{r|r|r|r|r|r|r}
\hline 4 月 & 5 月 & \multicolumn{1}{|c|}{6 月 } & \multicolumn{1}{|c|}{7 月 } & \multicolumn{1}{c|}{8 月 } & 9 月 & 10 月 \\
\hline 716 & 793 & 760 & 855 & 813 & 819 & 809 \\
\hline 38 & 39 & 7 & 133 & 111 & 99 & 104 \\
\hline 754 & 832 & 767 & 988 & 924 & 918 & 913 \\
\hline
\end{tabular}

（出所）日本石炭協会「石炭需給月報」
て新聞などに公表しているものが 909 万 $\mathrm{kW}$ あるが, この中半分が実現するものと想定すると，65年度の出 力は 1,966 万 $\mathrm{kW}$, 石炭消費量は 3,556 万トンとなる

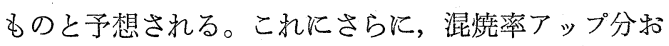
よび転換期待分 715 万トンとその中時期の固まってい るもの 238 万トンの中間値 477 万トンを 65 年度迄隹現 するものとして上記の石炭消費量に加えると，65年度 の石炭消費量は 4,033 万トンとなるるのと 予測される。因みに，54年11月末に発表さ れた電気事業審議会に上る石炭消費量の見 通し， 60 年度 $1,450 \sim 1,650$ 万トン, 65 年度 $3,800 \sim 4,200$ 万トンと比較して見ると, 本 予測値は大体一致しており, 電力業界飞拈 ける石炭転換への積極的な努力により政府 の見通しの実現の可能性は高まったと言い 得るが，他方石岸は“污い”といらイメージ が強く残って抢り, 計画通り石炭火力の建 設を進めることができるかどらかは今後電 力業界に課せられた大きな問題であろう。

1.2 セメント工業

セメント工業に招いても, 第二次石油危 


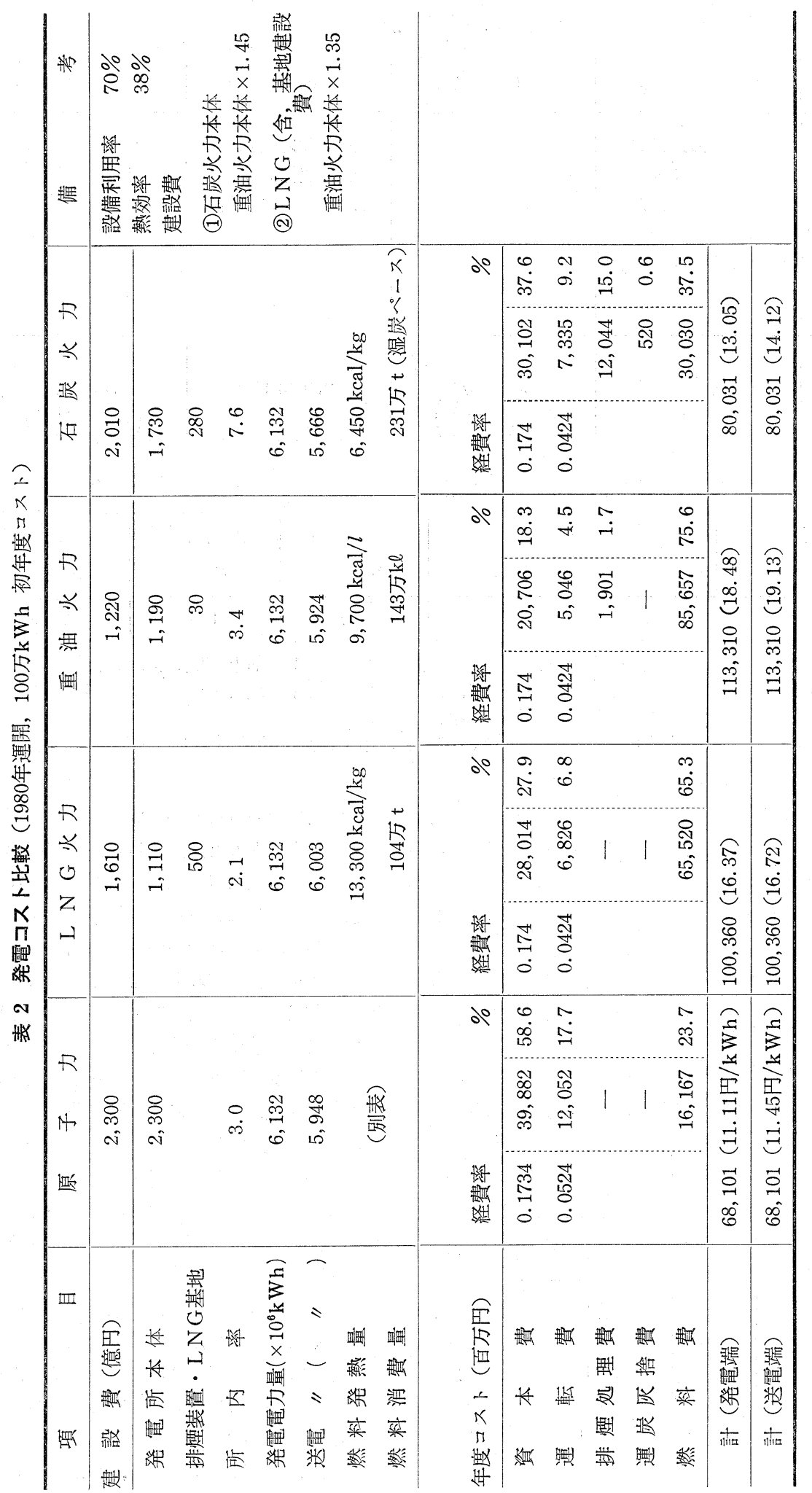


表 4 電

カ

（1）総 括 表

(単位 : 万 $\mathrm{kW}$, 万(湿) $\mathrm{t}$ )

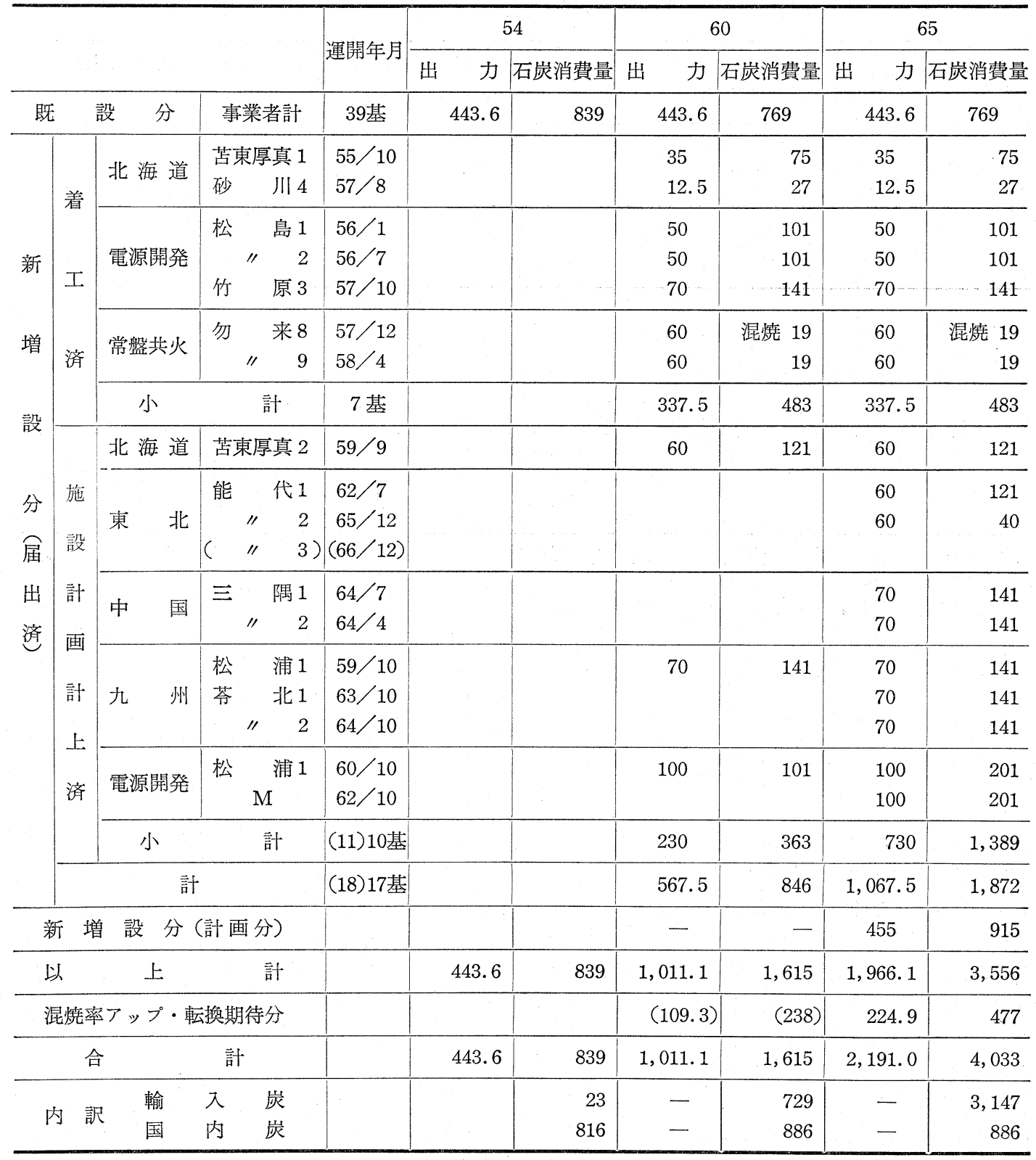

（注） 1. 新増設分 (届出済) の運開年月, 出力は電力各社「施設計画」による。

2. 石炭消費量はエネルギー経済研究所推定

3. 基数記載欄（）内，能代 3 のぞき 
（2）混焼率アップ・転換期待分

(単位 $:$ 万 $\mathrm{kW}$, 万(湿) $\mathrm{t}$ )

\begin{tabular}{|c|c|c|c|}
\hline & 出 力 & $\begin{array}{l}\text { 混燒率ア伴う増加転 } \\
\text { 揘) }\end{array}$ & 備 \\
\hline 混焼率アップ期待分 & 199.1 & 352 & $\begin{array}{l}55 \text { 年 } 3 \text { 月末現在の石炭・重油混焼火力の全部と勿来 } \\
8,9 \text { を計上 }\end{array}$ \\
\hline 転 換 期 待 分 & 224.9 & 363 & 55年 6 月末新聞等公表のもののみ \\
\hline 計 & - & 715 & \\
\hline \multicolumn{2}{|c|}{ らち時期の固まっているもの } & 238 & \\
\hline
\end{tabular}

（3） 新増設分（計画分） - 55 年12月末現在 新聞等公表ベースー

(単位 : 万 $\mathrm{kW}$ )

\begin{tabular}{|c|c|c|c|c|c|c|}
\hline & $\begin{array}{l}60 \text { 年代 前半 } \\
\text { 計 画 分 }\end{array}$ & $\begin{array}{l}60 \text { 年 代 後半 } \\
\text { 検 討 分 }\end{array}$ & & & $\begin{array}{l}\text { 代 前 } \\
\text { 画 分 }\end{array}$ & $\begin{array}{l}60 \text { 年代 後半 } \\
\text { 検 討 分 }\end{array}$ \\
\hline 北海道 & 45.60 （未定） & 45.60級 （未 定） & 四 国 & & - & \multirow{5}{*}{ 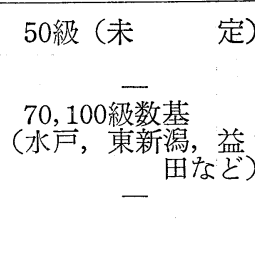 } \\
\hline 東京 & (水 $\stackrel{100 \times 3}{戸}$, 北茨城) & $\begin{array}{l}\text { 100級数基 } \\
(\text { 北茨城・相馬など） }\end{array}$ & 九 州 & 70 & （松 浦） & \\
\hline 部 & $60 \times 2$ (未 定) & 60級数基（未 定） & 電源開発 & & & \\
\hline 陸 & 一 & 100級（未 & その他 & $\begin{array}{l}16 \\
18 \\
\end{array}$ & $\begin{array}{l}\text { (沖 縄) } \\
\text { (住友共火) }\end{array}$ & \\
\hline 西 & $60 \times 3$ （未 & \multirow{2}{*}{ - } & 計 & \multirow{2}{*}{\multicolumn{2}{|c|}{909}} & \\
\hline 中 国 & （新小野田） & & & & & \\
\hline
\end{tabular}

機を契機として石油の供給制約と大幅な価格上昇が明 確になると共に，油炭格差が大きく拡大し，石炭転換 のメリットが著しく増大したため，54年末から石炭転 換への動きが急速に高まった。表 5 亿ょりその推移を 見ると，消費占める石炭転換率は 54 年度の $11.8 \%$ よ り 55 年 9 月には $48.5 \%$ へと大きく上昇して䟥り，55年 12月には $68 \%$ (速報值)へと上昇，その転換速度はき わめて急速である。56年度については，55年度の石炭 消費量見达 750 万トンに対し，セメント業界の計画で は石炭所要量は約 1,100 万トン，石炭転換率は $80 \%$ 近 く迄達する見込である。セメント業界としては，最終 的には石炭転換率 $90 \%$ と泀とんど石炭専焼にする計画 であるが，これを達成するには次のようないくつかの 障害を克服していく必要があり, 業界の計画が実現す るのはかなり先のこととなるものと予想され，少なく とも60年度迄に実現するためにはかなりの困難を伴な らものと考光られる。

第一に最も重要な問題であると考光られるのは，石
炭所要量に見合う石炭の供給を確保できるかどうかと いうことである。表 6 は，55年度に战汀る石炭の手当 状況を示したものであるが，まず輸入炭の主力となっ ている豪州炭については1984年積迄新規開発分字含め て売切れの状況にあり, 当面大きな供給増は期待でき ないことに加えて, カナダ炭は埋蔵量が多くないこ と, 中国炭は山元開発, インフラ整備が日本からの資 金協力によって行われているが建設のペースは1985年 完成といら計画より少なくとも $1 \sim 2$ 年遅れるのは不 可避であるとの見方が一般的であり，さらに埋蔵量が 多く最も期待される米国西部炭は積出し迄のインフラ の整備が早くて1990年頃となる見込であるということ を考光ると，1985年迄輸入炭の供給が大きく増加する 可能性は少ないと言えよう。また，国内炭について も， 55 年度は期初の石炭在庫が 178 万トンと高水準に あり，一般炭の需要増に対応して年度中に 150 万トン 取崩し, セメント業界も 200 万トンの国内炭を確保す ることができたが，今後国内炭の大きな増産の可能性 
表 5 石炭・重油等燃料消費高推移

(55.11.20)

\begin{tabular}{|c|c|c|c|c|c|c|c|c|}
\hline \multirow{2}{*}{ 年・月 } & \multicolumn{2}{|c|}{ 消＼cjkstart費 } & 高 & \multicolumn{3}{|c|}{ らち焼成用 } & \multirow{2}{*}{\multicolumn{2}{|c|}{$\begin{array}{c}\text { 石炭使用 } \\
\text { (焼成用) } \\
\text { 会社・工場数 }\end{array}$}} \\
\hline & 石 炭 & 重 油 & その他 & 石 炭 & 重 油 & その他 & & \\
\hline \multirow[b]{2}{*}{54 年度 } & $\begin{array}{r}\text { 千 } \mathrm{t} \\
(11.8)\end{array}$ & $\begin{array}{r}\text { 千kl } \\
(88.2)\end{array}$ & 千 kl & $\begin{array}{r}\text { 千 } \mathrm{t} \\
(12.5 \%)\end{array}$ & $\begin{array}{r}\text { 千kl} \\
(87.5 \%)\end{array}$ & 千 $\mathrm{k} \ell$ & & \\
\hline & 1,556 & 6,955 & - & 1,547 & 6,507 & - & 7 & $\frac{1}{16}$ \\
\hline \multirow{3}{*}{ 55年 4 月 } & $(22.9)$ & $(75.5)$ & $(1.6)$ & (24.3) & $(74.0)$ & ( 1.7$)$ & & \\
\hline & 238 & 471 & 10 & 237 & 434 & 10 & 9 & 18 \\
\hline & $(25.4)$ & $(72.7)$ & $(1.9)$ & $(26.6)$ & $(71.4)$ & $(2.0)$ & & \\
\hline 5 月 & 248 & 426 & 11 & 247 & 397 & 11 & 9 & 18 \\
\hline \multirow[b]{2}{*}{6 月 } & $(29.1)$ & $(68.7)$ & $(2.2)$ & $(30.5)$ & (67.1) & $(2.4)$ & & \\
\hline & 282 & 399 & 13 & 282 & 372 & 13 & 14 & 28 \\
\hline \multirow[b]{2}{*}{7 月 } & $(35.8)$ & $(62.9)$ & $(1.3)$ & (37.9) & $(60.7)$ & ( 1.4$)$ & & \\
\hline & 356 & 375 & 8 & 355 & 341 & 8 & 15 & 31 \\
\hline \multirow[b]{2}{*}{8 月 } & $(42.3)$ & $(55.8)$ & (1.9) & (44.7) & $(53.3)$ & $(2.0)$ & & \\
\hline & 379 & 300 & 10 & 378 & 270 & 10 & 17 & 34 \\
\hline \multirow[b]{2}{*}{9 月 } & $(48.5)$ & $(49.7)$ & $(1.9)$ & (50.9) & $(47.1)$ & $(2.0)$ & & \\
\hline & 480 & 295 & 11 & 479 & 266 & 11 & 18 & 37 \\
\hline \multirow{2}{*}{$\begin{array}{l}55 \text { 年 度 } \\
\text { 上 }\end{array}$} & $(33.8)$ & $(64.4)$ & $(1.8)$ & $(35.6)$ & $(62.5)$ & ( 1.9$)$ & & \\
\hline & 1,983 & 2,266 & 63 & 1,978 & 2,080 & 63 & & \\
\hline $\begin{array}{l}\text { 対 前 年 } \\
\text { 同期比\% }\end{array}$ & 387.3 & 65.5 & - & 389.6 & 64.2 & 一 & & \\
\hline
\end{tabular}

は注とんどないと同時に，在庫もすでに取崩してしま っていることを考觉ると，国内炭の供給量も55年度の 200 万トンを下回わると予想するのが妥当であろう。 以上から見て, セメント業界が, 計画通り石炭の供給 を確保することはきわめて大きな困難を伴ならるのと 考宎られる。

第二には，セメント業界に款いては， $\mathrm{SO}_{x}$ ，灰は原 料の中に混入し問題はないが，既設キルンに対する $\mathrm{NO}_{x}$ 規制值 $480 \mathrm{ppm}$ にどら対応するかという問題が 残されている。石炭には窒素分が石油より多く含まれ ているため, 石炭混焼率の引上げと共に $\mathrm{NO}_{x}$ 排出量 が增加して和り, 設備改造一 4 段サイクロンを5 段サ イクロンへと増設し且つ堅型を横型にする一，アンモ ニア脱硝法の導入なぞによって対応する外, 効率の悪 いキルンの場合には石炭混焼率の引下げによって対応 さぜるを得ないものと考光られている。

以上のような石炭混焼率引上げに対する障害から見
表 6 55年度におけるセメント業界の石炭手当状況 (単位 : 1,000 M. T.)

\begin{tabular}{|c|c|c|c|}
\hline & & & 55 年 度 \\
\hline & 交所要 (A) & & 7,500 \\
\hline 輸 & 豪 州 & & 4,000 \\
\hline & & & 500 \\
\hline 人 & 中 国 & & 250 \\
\hline 炭 & ソ・南了 & & 100 \\
\hline 小 & 計 & & 4,850 \\
\hline & 内 炭 & & 2,000 \\
\hline & 給 計(B) & & 6,850 \\
\hline & $3)-(A)$ & & $\triangle 650$ \\
\hline & 足 対 策 & 米炭手当 & 500 \\
\hline & 的 & ミル分譲 & 180 \\
\hline
\end{tabular}


表 7 セメント

(単位: 千 $\mathrm{t}$ (湿), $\mathrm{k} \ell / \mathrm{t}, 千 \mathrm{k} l, \%$ )

\begin{tabular}{|c|c|c|c|c|c|c|c|}
\hline & & \multirow{2}{*}{ 実 績 } & \multicolumn{2}{|l|}{ 予 } & \multicolumn{2}{|c|}{ 年平均伸び率 } & \multirow{2}{*}{ 予 測 根 拠 } \\
\hline & & & 60 & 65 & $60 / 54$ & $65 / 60$ & \\
\hline & リンカー生産量 & 90,216 & 105,900 & 121,000 & 2.7 & 2.7 & \multirow{2}{*}{$\begin{array}{l}48 \sim 54 \text { 年伸び率 }(2.7 \%) \text { 延長 } \\
52 \sim 54 \text { 年平均減分の半分程度 }\end{array}$} \\
\hline & 油 換 算 原 単 位 & 87 & 80 & 75 & - & - & \\
\hline & 油 換 算 量 & 7,849 & 8,472 & 9,075 & 1.3 & 1.4 & \multirow{6}{*}{$\begin{array}{l}\text { 発電用重油を含まない } \\
\left.\begin{array}{ll}\text { 重油換算量 } \times 1.61 & \text { 混分 } \\
\qquad(9,800 \mathrm{kcal} / 6,500 \div 0.938\end{array}\right)\end{array}$} \\
\hline & 炭 換 算 量 & 12,712 & 13,640 & 14,610 & 1.2 & 1.4 & \\
\hline 石 & 石炭 転 換 率 & 12.2 & 75.0 & 85.0 & - & - & \\
\hline 炭 & 消費量 (転換量) & 1,556 & 10,230 & 12,420 & 36.9 & 4.0 & \\
\hline 費 & 輸 入 炭 & 1,037 & 9,230 & 10,920 & - & - & \\
\hline 量 & 国内炭 & 519 & 1,000 & 1,500 & - & - & \\
\hline
\end{tabular}

（注） 実績の出所：通産省「割業統計年報」，セメント協会資料，およびェネルギー経済研究所推定

表 8 最近における石炭消費量および石炭ボイラー稼㗢状況

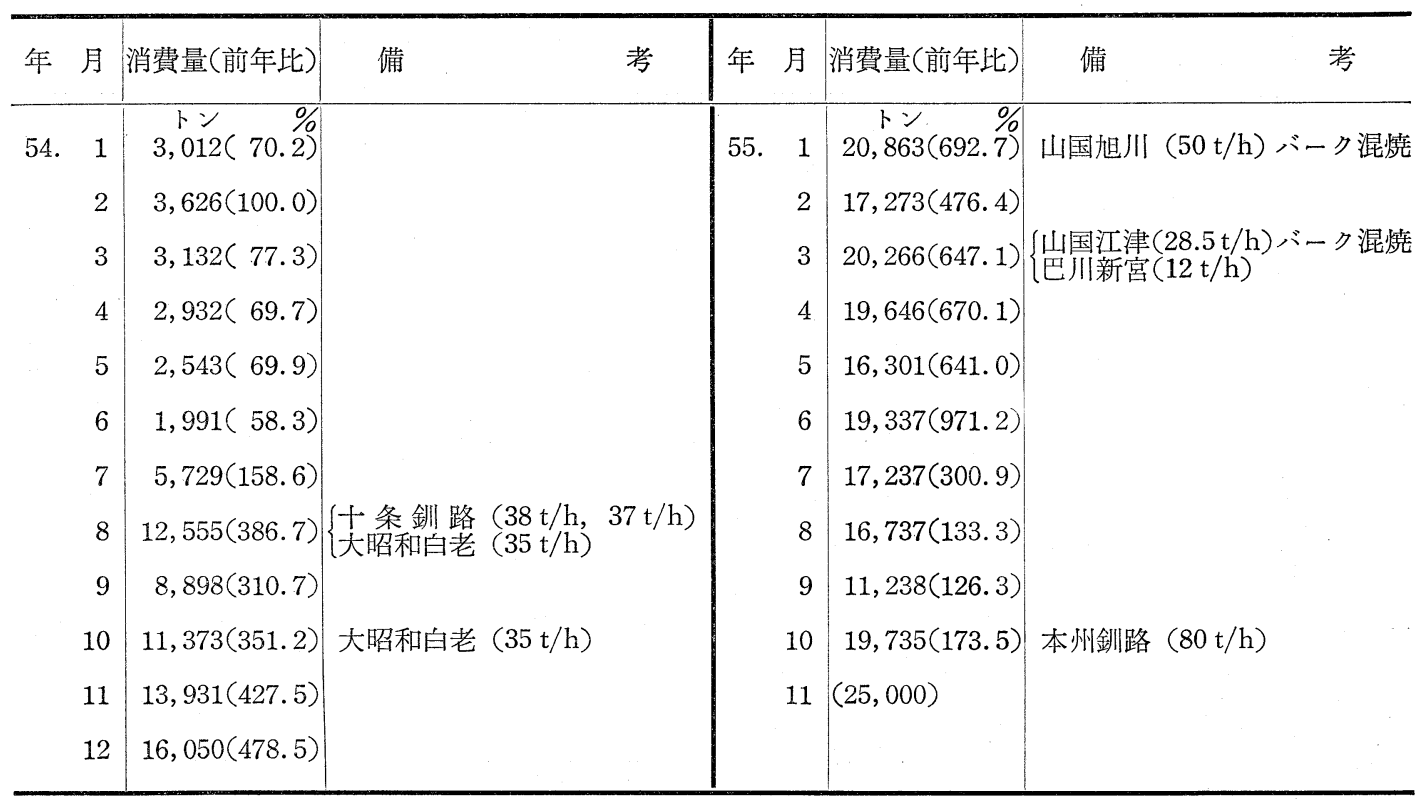

（出所）製紙連合会資料 
表 9 紙・パルプ業界における石炭転換計画

（55年10月現在）

\begin{tabular}{|c|c|c|c|c|c|c|c|c|c|c|}
\hline 会 & 社 & 名 & 工 & 場 & 名 & 転 換 形 & 態 & ボイラー台数 & 転换 時期 & 蒸気発生量 \\
\hline 王 & 子 製 & 紙 & $\begin{array}{l}\text { 苫 } \\
\text { 米 }\end{array}$ & 小 & $\begin{array}{l}\text { 牧 } \\
\text { 子 }\end{array}$ & $\begin{array}{ll}\text { 再 } & \text { 稼 } \\
\text { 再 } & \text { 転 } \\
\text { 再 } & \text { 稼 }\end{array}$ & $\begin{array}{l}\text { 働 } \\
\text { 換 } \\
\text { 働 }\end{array}$ & $\begin{aligned} 2 \mathrm{~B} \cdot 3 \mathrm{~B} \cdot 4 \mathrm{~B} \\
7 \mathrm{~B} \\
5 \mathrm{~B}\end{aligned}$ & $\begin{array}{c}\text { 昭56.4 } \\
59 \\
56.3\end{array}$ & $\begin{array}{l}(\mathrm{t} / \mathrm{h}) \\
108 \\
200 \\
30\end{array}$ \\
\hline+ & 条 製 & 紙 & 釧 & " & 路 & $\begin{array}{l}\text { 䨪 } \\
\text { 稼 } \\
\text { 転 }\end{array}$ & $\begin{array}{l}\text { 働 } \\
\text { 換 }\end{array}$ & $\underset{6 \mathrm{~B}}{2 \mathrm{~B} \cdot 5 \mathrm{~B}}$ & $\begin{array}{l}54.8 \\
56.1\end{array}$ & $\begin{array}{l}75 \\
60\end{array}$ \\
\hline 本 & ，州 製 & 紙 & 釧 & & 路 & 再＼cjkstart転 & 換 & $7 \mathrm{~B}$ & 55.11 & 80 \\
\hline & 昭和製 & 紙 & 白 & " & 老 & $\begin{array}{ll}\text { 再 } & \text { 稼 } \\
\text { 再 転 }\end{array}$ & $\begin{array}{l}\text { 働 } \\
\text { 換 }\end{array}$ & $\begin{array}{l}4 \mathrm{~B} \cdot 5 \mathrm{~B} \\
1 \mathrm{~B} \cdot 2 \mathrm{~B}\end{array}$ & $\begin{array}{c}54.8 \sim 10 \\
55 \text { 末 } \sim 56 \text { 初 }\end{array}$ & $\begin{array}{l}70 \\
76\end{array}$ \\
\hline & 昭和 ハ八 & プ & 岩 & & 沼 & 新 & 設 & $4 \mathrm{~B}$ & $56 \sim 57$ & 250 \\
\hline & 陽国策パ & & 量 & & $\begin{array}{l}\text { 川 } \\
\text { 津 } \\
\text { 払 }\end{array}$ & $\begin{array}{l}\text { 再 } \\
\text { 㓷 } \\
\text { 新 }\end{array}$ & $\begin{array}{l}\text { 働 } \\
\text { 換 } \\
\text { 設 }\end{array}$ & $\begin{array}{rl}5 & \mathrm{~B} \\
2 \mathrm{~B} \\
10 \mathrm{~B}\end{array}$ & $\begin{array}{l}55.1 \\
55.3 \\
58\end{array}$ & $\begin{array}{l}50 \\
28.5 \\
300\end{array}$ \\
\hline 北 & ：陽 製 & 紙 & 名 & & 寄 & 再 転 & 換 & $2 \mathrm{~B}$ & 56 & 30 \\
\hline 三 & 菱 製 & 紙 & 八 & & 戸 & 新 & 設 & $4 \mathrm{~B}$ & 58 & 200 \\
\hline 日 & 光 製 & 紙 & 日 & & 光 & （常 & 用) & 1 & （32年～) & 52 \\
\hline 巴 & 川 製 & 紙 & 新 & & 宮 & 再 稼 & 働 & 1 & 55.3 & 12 \\
\hline 大 & 竹 絓 & 業 & 本 & & 社 & 新 & 設 & $8 \mathrm{~B}$ & 57 & 200 \\
\hline 大 & 王 製 & 紙 & 三 & & 島 & 新 & 設 & $\stackrel{17 \mathrm{~B}}{11 \mathrm{~B} \cdot 15 \mathrm{~B}}$ & $\begin{array}{l}58 \\
58\end{array}$ & $\begin{array}{l}350 \\
160\end{array}$ \\
\hline
\end{tabular}

60 年度の石炭消費量 (単位 : $1,000 \mathrm{M}$. T. )

\begin{tabular}{|c|c|c|}
\hline & & 石炭消費量 \\
\hline \multicolumn{2}{|c|}{ 再稼働, 再転換分 } & 1,147 \\
\hline 新 & 設 & 1,030 \\
\hline 合 & 計 & 2,177 \\
\hline
\end{tabular}

（注）上記の外飞神崎製紙富岡工場 $(40 \mathrm{t} / \mathrm{h})$, 尼崎工場 $(30 \mathrm{t} / \mathrm{h} \times 2)$ が検討中。 （出所） 製紙連合会資料

て，業界の計画通り石炭転換が実現するのは難しいと 思われ，表 7 亿示すように 60 年度で石炭転換率 $75 \%$, 石炭消費量 1, 023 万ト 2,65 年に石炭転換率 $85 \%$ ，石 炭消費量 1,242 万トンと予測するのが可成控兄目であ るが現実的な見方であろう。

\section{3 紙・パルプ産業}

紙・パルプ産業に和ける石炭消費量の推移は表 8 亿 示す通りであり，石炭消費量は, 54年 1 月の約 3,000 卜 ン/日の低水準から55年10月には約 20,000 トン/日の水 準へと大きく増加している。これは，表 9 に示すよう な石炭転換計画によるものであるが，今迄のところ石
炭ボイラーを解体せずに残して特いた予借罐の再稼動 ないし石炭焚きのボイラーから石油焚きへと転換して いた石炭ボイラーの再転換が石炭転換の動きであり， 大型の石炭ボイラーの新設は56年以降となる計画であ る。従って, 今迄の石炭転換に伴なら石炭所要量の確 保は主として国内炭によって賄って和り，輸入炭は今 後新設される石炭消費量の多い大型石炭ボイラー向け となろら。しかし，紙・パルプ業界に抢ける石炭転換 も, セメント業界と同様, 石炭の供給が確保されるか どらか，環境規制，特に $\mathrm{NO}_{x}$ 規制に対してどら対応 するかといら大きな問題がある外，灰処理，二次輸送 
表 10 紙・パルプ

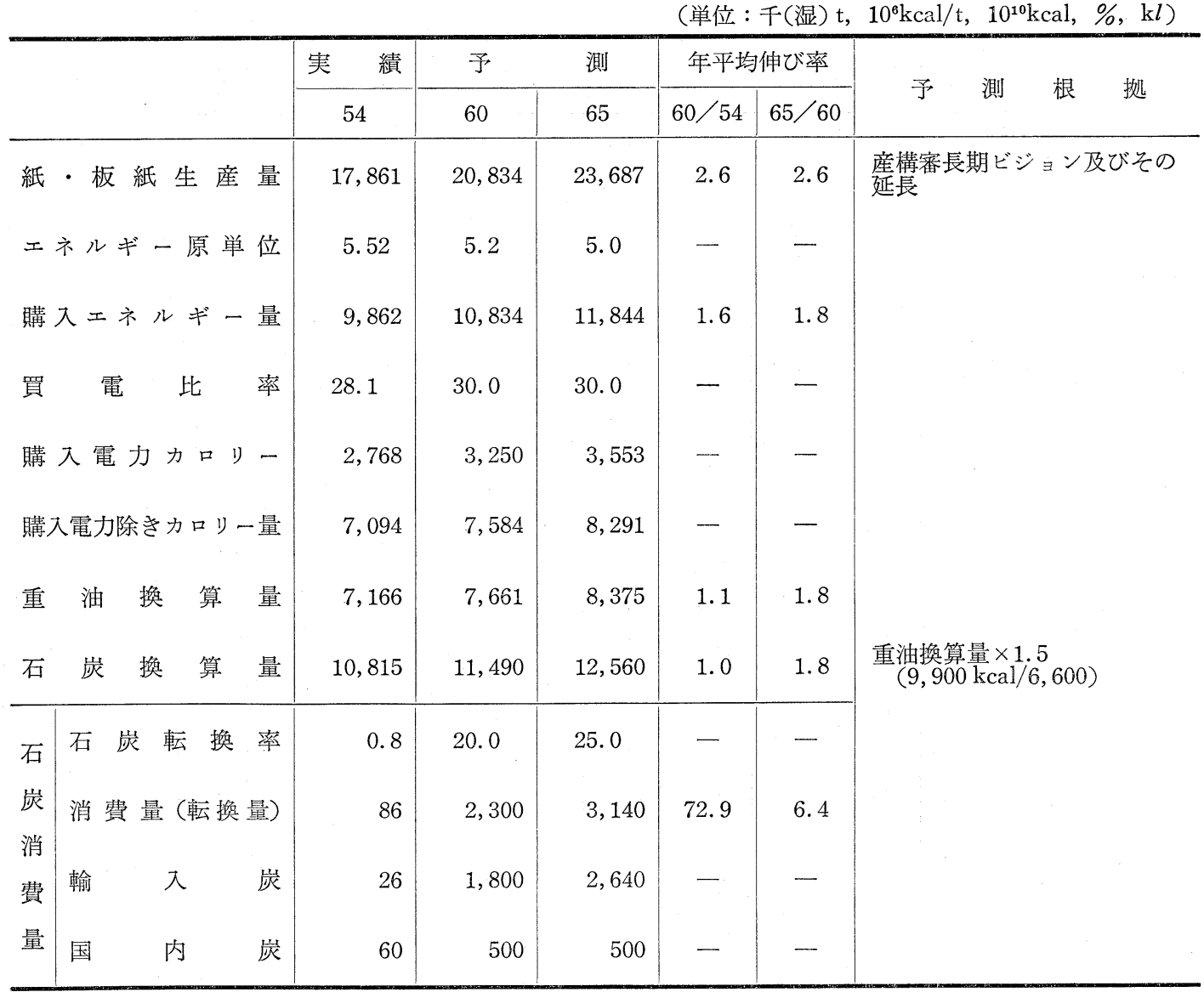

（注） 実績の出所：通産省「紙パルプ統計年報」及びエネルギー経済研究所推定

の確保などいくつかの問題を克服していく必要があ り，表 9 に示す 60 年度の石炭消費量約 220 万トンは, 以上のような障害ないし問題点が順調に克服されてい くことを前提とするものであろら。従って, 若干楽観 的ではあるが業界の石炭転換計画をべースとして将来 の紙・パルプ産業に和ける石炭消費量を予測すると， 表10に示すように60年度で石炭転換率 $20 \%$, 石炭消費 量 230 万トン，65年度には石炭転換率 $25 \%$, 石炭消費 量 314 万トンとなるものと予測される。

\section{4 鉄 鋼 業}

鉄鋼業に叔いては54年秋より高炉のオールコークス 操業が積極的飞推進されて特り, 日本鋼管, 川崎製 鉄, 神戸製鋼が56年 1 月 22 日迄にすべての稼動高炉を オイルレス操業に切り替えた外，新日本製鉄も56年 6 月末迄にすべての稼動高炉をオイルレス操業に切り替 える計画である。事実, 高炉の燃料比の推移を見て
も，53年度のコークス比 $426 \mathrm{~kg}$, オイル比 $35 \mathrm{~kg}$ に対し 55 年 11 月の大手 5 社の実績ではコークス比 $455 \mathrm{~kg}$, オ イル比 $10 \mathrm{~kg}$ とコークス比は若干增加しているものの, オイル比は $1 / 3$ と大幅な低下を示している。このよう なオールコークス操業を中心とするオイルレス操業へ の転換を進める一方, 鉄鋼業界としては COM, CTM (石炭・タール混合然料), 微粉炭などの高外への次込 実験を開始し，高炉吹达用燃料の多様化を図ってい る。COM は新日本製鉄，住友金属の 2 社，CTM は 日本鋼管，微粉炭吹达は新日本製鉄がそれぞれ高炬へ の吹込実験をすでに開始して括り，ここ $1 \sim 2$ 年の間 に和ける吹込実験の後実用化され，高炉吹込用燃料の 多様化の一環として鉄鋼業界に和いても一般炭の利用 拡大の可能性が大きく開けて来た。これら高炉吹込用 の一般炭の使用量としては, 銑鉄トン当り $10 \mathrm{~kg}$ 程度と 予想され，一般炭使用量は60年度で 98 万ン，65年度 
表 11 鉄

(単位: 千 $\mathrm{t}($ 湿), \%, $\mathrm{kg} / \mathrm{t}$ )

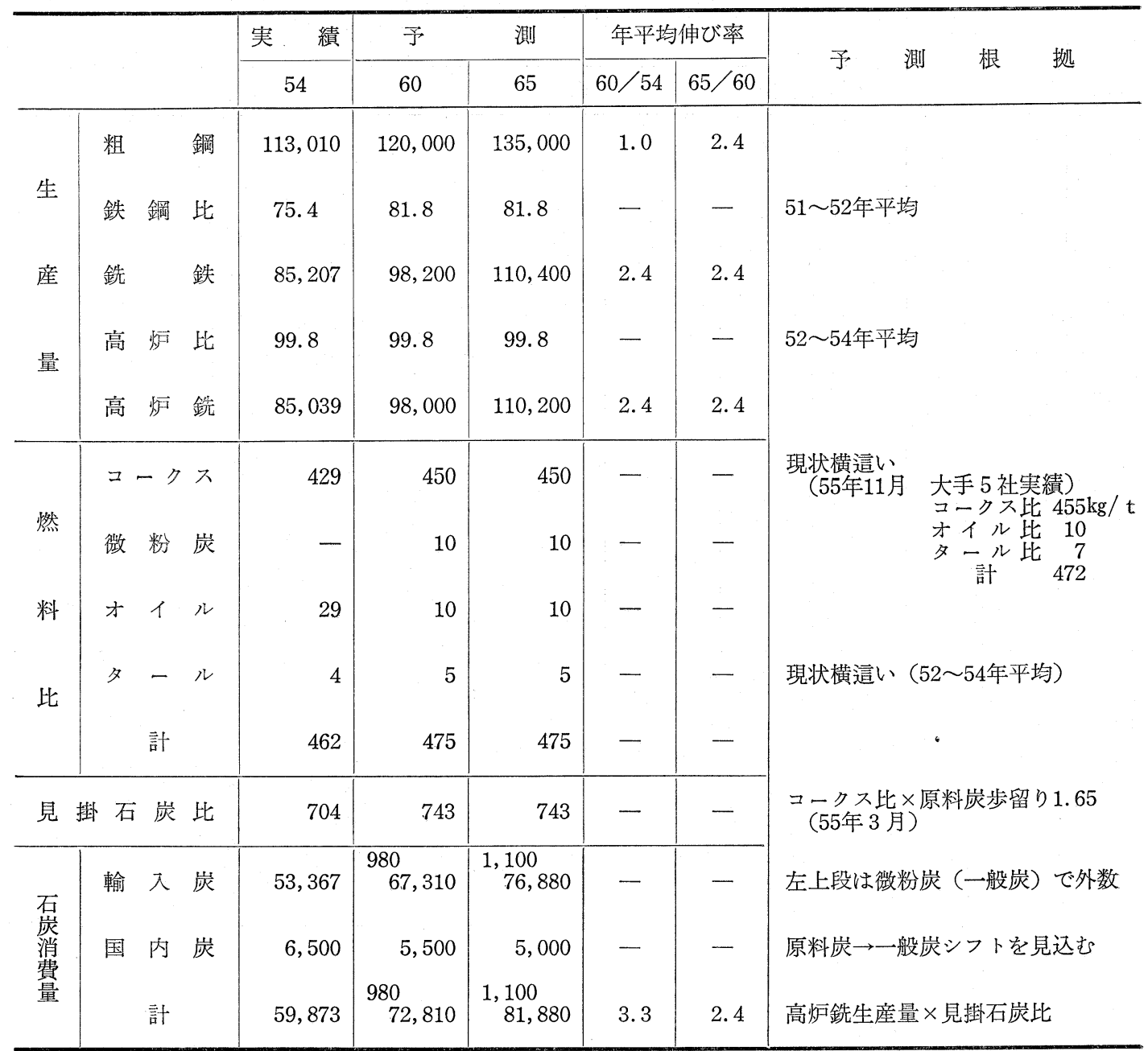

（注） 実績の出所：通産省「鉄鋼統計月報」呿よび鉄鋼連盟資料

に110万トンと約 100 万トン程度の水準に上るものと想 定される。

\section{5 産 業計}

以上のような主要石炭需要産業に打ける石炭消費の 見通し一その他の産業は，供給確保，環境規制，灰処 理，用地および輸送体制などの面で制約が大きく，潜 在的な石炭需要はあっても現実には需要増は期待でき ないものと考え 53 年度実績の横這いとする一を基にし て，産業全体に和ける石炭消費の見通しをまとめたの が, 表12である。これによると, 輸入一般炭の見通し は，60年度で 2,034 万トン，65年度に 4,717 万トンであ り，60年度迄はセメント工業が中心となって伸び， 65
年度にかけては電力事業が中心となって大きく伸び， 全体としての輸入一般炭の需要量の拡大に寄与してい る。これに対して政府による輸入一般炭の見通しで は, 60 年度 2,200 万トン, 65 年度 5,600 万トン（暫定見 通しに括ける 5,350 万トンは代替エネルギー供給目標 に抒いて 5,600万トンへ上向き修正された）となって おり，60年度については本予測と大きな差はないもの の，65年度については約 900 万トンの差がある。これ は, 何よりも政府の見通しに执いては, セメント工業 を中心とする一般産業による石炭消費が65年度にかけ てかなり大きく伸びるものと予想しているのに対し， 本予測では石炭消費の拡大に対する 制約条件が大き 
表 12 産業計

(単位 : 万(湿) $\mathrm{t}$ )

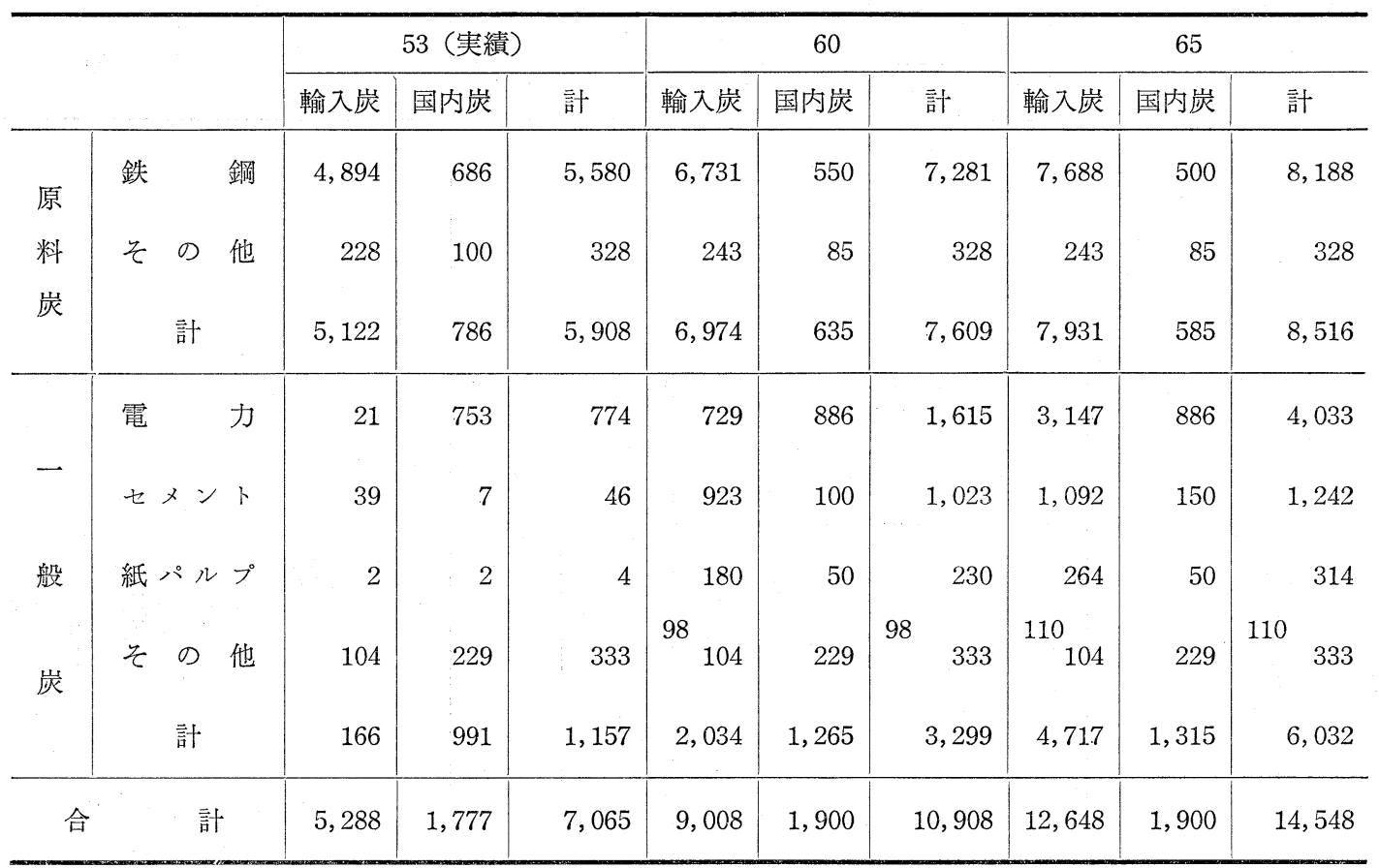

（注）一般炭・その他欄 左上段值は，鉄鋼微粉炭 (一般炭)で外数。一般炭計。合計には含む。

表 13 コールチェーンの要投資額

（億円）

\begin{tabular}{|c|c|c|c|c|c|c|c|}
\hline & 海外炭開発 & 石 炭 船 & $\begin{array}{l}\text { ユールロ } \\
\text { センター }\end{array}$ & $\begin{array}{l}\text { 石炭火力 } \\
\text { 篦 所 }\end{array}$ & $\begin{array}{c}\text { セxント } \\
\text { キルン }\end{array}$ & その 他 & 合 \\
\hline 所要投資額 & $\begin{array}{ll}※ & \\
& 1,600\end{array}$ & 8,900 & 2,100 & 56,000 & 900 & 1,400 & 70,900 \\
\hline 投資主体 & $\begin{array}{l}\text { 開発参加者 } \\
\text { 商 社 等 }\end{array}$ & $\begin{array}{l}\text { 海 運 業界 } \\
\text { ニーザー }\end{array}$ & $\begin{array}{ll}\text { 第 } & 3 \\
\text { セクタ }\end{array}$ & 電力業界 & $\begin{array}{l}\text { セメント } \\
\text { 業 界 }\end{array}$ & $\begin{array}{l}\text { 紙パ， } \\
\text { 繊維等 } \\
\text { その他業界 }\end{array}$ & \\
\hline 備 & $\begin{array}{l}\text { 鉱山会社への } \\
\text { 出資金, 開発 } \\
\text { 利権取得費 }\end{array}$ & $\begin{array}{c}10 \text { 万重量トン } \\
110 \text { 隻 }\end{array}$ & $\begin{array}{c}\text { 経由量 } \\
\text { 30百万トン }\end{array}$ & $\begin{array}{l}22 \text { 23百万 } \\
\text { KWの新設 }\end{array}$ & $\begin{array}{l}\text { キルンの石 } \\
\text { 炭専焼・混 } \\
\text { 焼化 }\end{array}$ & $\begin{array}{l}\text { ボイラーの } \\
\text { 石炭専焼・ } \\
\text { 混焼化 }\end{array}$ & $\begin{array}{l}\text { ※参加比率に } \\
\text { 資額。投 }\end{array}$ \\
\hline
\end{tabular}

(出所)：三和銀行「経済月報」55年12月号

く,このため特に一般産業に和いては石炭利用拡大に 対する障害となり，60年度にかけて大きく伸びると予 想されるセメント工業を除いて一般産業に和ける石岸 消費の大きな伸びは期待できないものと考光たことに よるものである。その意味においては，政府見通しに 示されるように石炭の利用拡大を急速に進めるために は，石炭消費の拡大に対するいくつかの制約条件ない
し障害を取除くための努力を官民の関係者が積極的に 推進することが必要とされよう。

\section{2. コールチェーンの確立}

2.1 概 要

前述のような一般炭の利用拡大の見通しを実現する ためには，何よりも山元一積出し迄の輸送一積出し港 湾一一次輸送一中継基地一二次輸送一石炭需要家とい 
一般炭利用拡大とコールチェーンの確立（千村）

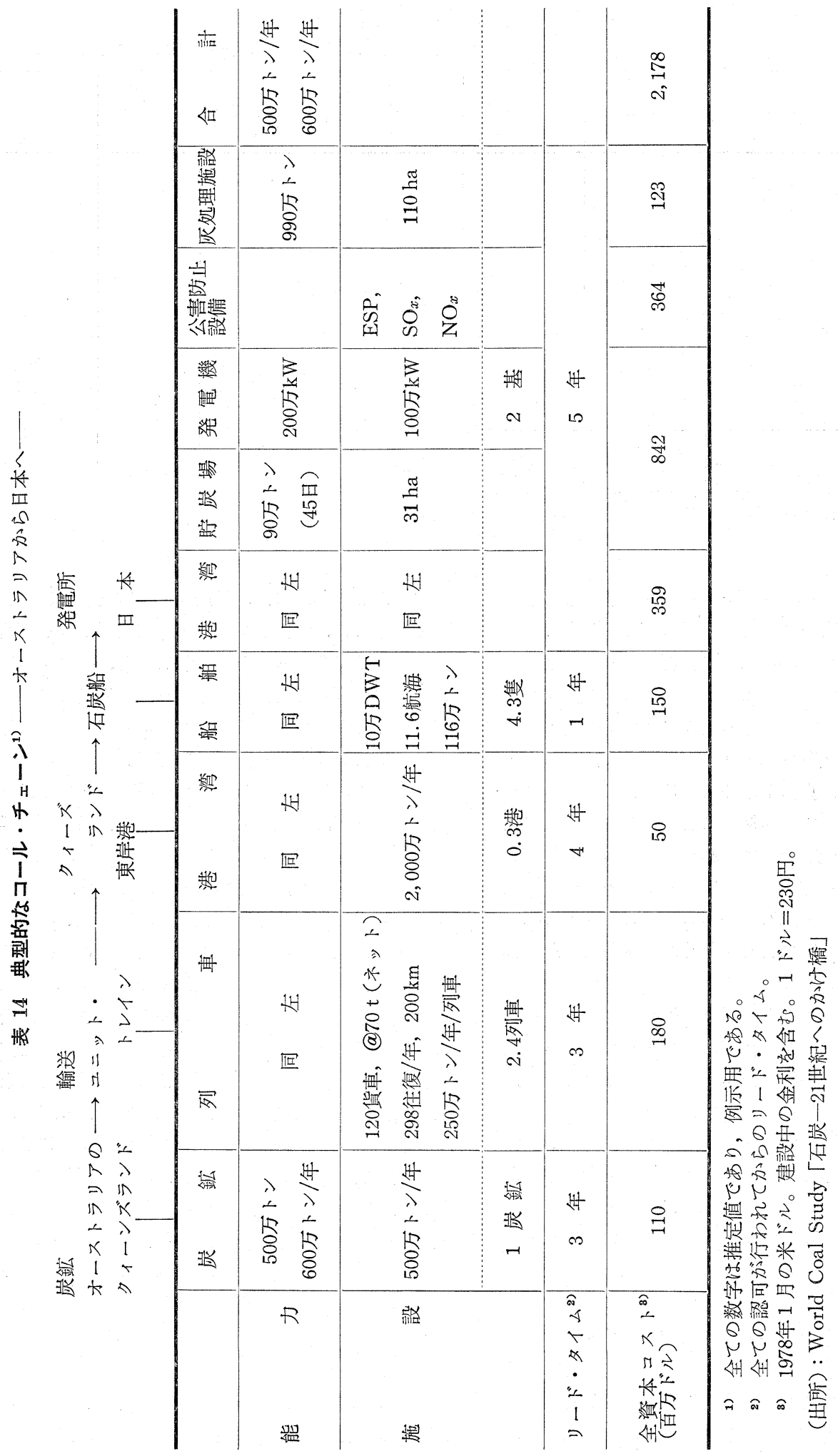


表 15 石炭供給チェーンにおける投資額

（1978年価格での年間石岸 1 トン当たりドル）

\begin{tabular}{|c|c|c|c|c|c|c|c|}
\hline 積 & 出 & 目的地 & 崖 & 内陸輸送 & 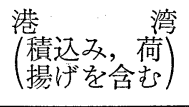 & 船 & 合 \\
\hline \multicolumn{2}{|c|}{$\begin{array}{l}\text { オーストラリア・グインーンズ } \\
\text { ランド近の計画例) }\end{array}$} & 極 東 & 22 & 36 & 20 & 30 & 108 \\
\hline \multicolumn{2}{|c|}{$\begin{array}{l}\text { オーストラリア・グィーンズ } \\
\text { ランド州 (計画中) }\end{array}$} & 極 & 58 & 14 & 28 & 30 & 130 \\
\hline \multicolumn{2}{|c|}{$\begin{array}{l}\text { オーストラリア・ニューザウ } \\
\text { スウェールズ州 }\end{array}$} & オランダ & 62 & 17 & 20 & 70 & 169 \\
\hline \multicolumn{2}{|c|}{ カナダ西部 } & オランダ & 94 & 45 & 30 & 83 & 252 \\
\hline \multicolumn{2}{|c|}{ カナダ西部 } & デンマーク & 20 & 8 & 8 & 73 & 109 \\
\hline \multirow{2}{*}{\multicolumn{2}{|c|}{ アメリカ西部 }} & 極 & 60 & 15 & 30 & 70 & 175 \\
\hline & & 平 & $\begin{array}{c}53 \\
20-94\end{array}$ & $\begin{array}{c}23 \\
8-45\end{array}$ & $\begin{array}{c}23 \\
8-30\end{array}$ & $\begin{array}{c}59 \\
30-83\end{array}$ & $\begin{array}{c}158 \\
108-252\end{array}$ \\
\hline
\end{tabular}

(出所) : World Coal Study「石炭一21世紀へのかケ橋」

ら石炭の流れ，所謂コールチェーンを整備することが 不可欠である。表13は，三和銀行調査部が算出したコ ールチェーンを完成するために必要な 55-65 年度間の 累計投資額を示したるのであるが，ここで注目すべき ことはコールチェーン全体の整備に要する投資額 7 兆 円の中 $82 \%$ を石炭利用設備関連投資が占め, しかもそ の汇とんぞを石炭火力が占めていることである。これ を表14によって見ても同様のことが指摘され，石炭火 力発電所関連投資額が全体の約 $78 \%$ を占めている。し かし, 石炭利用設備上の問題は前述の一般炭の利用拡 大の展望の部分でも触れていること，また電力を除い ては資金上の問題はあまり大きくないものと考光られ ることから，ここではュールチェーンの中海外炭鉱開 発と輸送体制の問題を取上げて検討して見たいと思 う。中でも輸送関連投資額は, 表13〜表15によって見 ると，石炭利用設備関運投資を除いた残りの67～87\% に上り,コールチェーンの問題は, ある意味に拈いて は輸送体制の問題であると言っても過言ではない程大 きな重要性を持っている。従って, 輸送体制を中心と してコールチェーンの確立のためにはどのような問題 点があり，それを克服するためにはどのように対応し たらよいか若干指摘して見ることとしたい。

\section{2 海外炭開発}

表16により日本の企業グループの炭鉱開発への参加 比率（埋蔵量ベース）を見ると, 約 $13 \%$ あまり高く なく，また表13により海外炭開発関連投資額を見ても 1,600 億円と金額的にも驚く程 多額のものではない。
しかし，資本参加には，(1)炭鉱の経営内容を知ること ができること，(2)受取配当によって石炭の入手価格を その分だけ相殺することができること，(3)供給の安定 性を確保できること，(4)日本からの投術協力の機会が 得られることなどのメリットがあるので，日本として は積極的に資本参加し，炭鉱の開発を推進する必要が ある。特に，現在のように根強い石炭に対する潜在需 要がある一方，それ対応した石炭の供給が十分に確 保できない状況の下に招いては，石炭価格は急速に上 昇する恐れがあり，これに対する最善の対応策は，石 炭の生産力と積出し能力を拡張し, 供給 余力を創出 し，それによって石炭価格の安定を図ることにある。 そのためには，何よりも積極的な先行投資によって石 炭の生産余力を作り出すことが先決であり，それを基 にして鉄道，港湾などの積出し迄のインフラを整備 し，日本が率先して石炭の開発輸入を推進することに よって産炭国石炭の供給上の余力を持たせること が，石炭価格の安定と石炭の利用拡大のために不可欠 の重要性を持っている。それと同時に，低品位炭の利 用による使用炭種の拡大拉よび豪州炭への過度の集中 を回避するための中国炭，米国西部炭の開発輸入の促 進による，一般炭供給先の分散により，供給上のリス クを軽減することが肝要である。

\section{3 輸送体制の整備}

\subsection{1 外航船舶}

表17に示すように, 前述の 65 年度の輸入一般炭 4,717 万トンを輸送するのに必要な外航船舶は,ケース $\mathrm{A}$ 
表 16 わが国企業・グループの利権確保状況（埋蔵量ベース）

(単位：万トン)

\begin{tabular}{|c|c|c|c|c|c|c|c|c|}
\hline & & & & 原 料 炭 & 一般崖 & $\begin{array}{l}\text { 原料炭+一般炭 } \\
\text { 区分不明のも }\end{array}$ & 合計 & $\begin{array}{c}\text { 昆本 側 } \\
\text { 参加比率平均 } \\
(\%)\end{array}$ \\
\hline \multirow{4}{*}{ 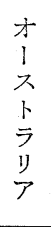 } & \multirow{2}{*}{ N.S.W. } & 日 & 本側 & 2,649 & 20,326 & 6,599 & 29,574 & \multirow{2}{*}{13.3} \\
\hline & & & ュジェクト計 & 42,400 & 121,400 & 58,100 & 221,900 & \\
\hline & \multirow{2}{*}{ Q.L.D. } & 日 & 本 & 8,427 & 10,800 & 1,067 & 20,294 & \multirow{2}{*}{10.5} \\
\hline & & & ロジェクト計 & 104,405 & 83,700 & 5,336 & 193,441 & \\
\hline \multirow[t]{2}{*}{ カ } & \multirow{2}{*}{ B. C. } & 日 & 側 & 5,179 & - & - & 5,179 & \multirow{2}{*}{22.9} \\
\hline & & & ジェクト計 & 22,624 & - & - & 22,624 & \\
\hline \multirow[b]{2}{*}{ ダ } & \multirow{2}{*}{ Alberta } & 日 & 本 側 & 2,080 & 1,500 & - & 3,580 & \multirow{2}{*}{35.1} \\
\hline & & & ジェクト計 & 5,200 & 5,000 & - & 10,200 & \\
\hline \multirow{2}{*}{ i } & \multirow{2}{*}{ 計 } & 日 & 本 側 & 18,335 & 32,626 & 7,666 & 58,627 & \multirow{2}{*}{13.1} \\
\hline & & & ジェクト計 & 174,629 & 210,100 & 63,436 & 448,165 & \\
\hline
\end{tabular}

（注）わが国企業・グループが直接・間接に出資している主要な炭鈗プロジェクト(交渉中のものを含む) の埋蔵量のうち利権相当分を日本側確保分として仮定算出した。

(65,350 dwt) で72隻, ケースB $(111,230 \mathrm{dwt})$ で40 隻である。さらに，これらの必要な外航船舶を建造す るの要する投資額は, ケース Aで 4, 318 億円, ケー ス Bで 2,950 億円である。これは全量日本船で輸送し た場合の投資額であるが，これを現在の用船も含めた 積取比率 $80 \%$ とすると 3,454 億円と2,360億円となり， これをさらに現在の日本船のみの積取比率50\%とする と2,159億円と1,475億円となる。しかし，石炭輸送の 安定性といら面から考兄て, 日本船隊拡充の必要性は 高いものがあるので, 積取比率80\%は日本船で確保す る必要があると考兄られ，そのためには現在の計画造 船を拡充することによって2, 400〜3, 500億円に上る建 造費の民間による負担を軽減することが不可欠であ る。それと同時に，大口の石炭需要家は単独で，また 小口需要家は他の需要家之協力して長期積荷保証を行 い，それによって石炭専用船の運航の安定性と運賃低 減の実現を図るだけでなく，他業種の石炭需要家との 協力により大型の石炭専用船の共同運航を行い，大型 石炭専用船の運航の合理化を図ることにょって運賃低 減のメリットを十分享受できる体制を整備することが 必要である。

\subsection{2 中継基地（コールセンター）}

65 年度迄に必要な石炭の中継基地による取报量は, 表18に示すように 3,142 万トンに上る。しかし，現在
の一般炭の輸入量 60 万トン強/月, 年率にして約700万 トンは，エヌケーコールセンターを中心とするすでに 稼動しているコールセンター，拉よび公共埠頭などの 現有設備によって中継輸送がすでに行われているもの と考学られるので， 3,142 万トンより現有設備による 中継輸送分 700 万トンを盖引くと，65年度迄に新規に 必要な中継基地取扱量は，2,442 万トンとなる。さら に，コールセンターを新規に建設してメリットが生じ ると考光られる 750 万トン/年 の取扱量をコールセン ター 1 力所の標準的な取扱い量とすると 3.3 力所程度 が新規に建設する必要のあるコールセンターの数とな る。しかし，表19により現在コールセンターとして建 設される予定の候補地を見ると16力所子あるが，この 中すでに本格的に稼動しているェヌケーコールセンタ 一, ここ $1 \sim 2$ 年の中に本格的に稼動すると予想され る響灘，宇部コールセンターおよび電力業界が中心と なって建設を推進している苫東厚真, 崎戸コールセン ターを除いては, 石炭の取扱需要量が計画の取扱量に 達しないコールセンターがほとんどであり，そのため コールセンターの建設の候補地は数多くあるものの, コールセンターとして本格的に稼動する可能性のある ものは上記の 5 力所飞過ぎない状況にある。従って, これら数多くあるコールセンターの候補地を調整し, 石炭の取扱量が一定の採算の取れる水準に達するコ一 
表 1765 年度汽に必要な外航船舶と投資額（55年価格，以下同じ）

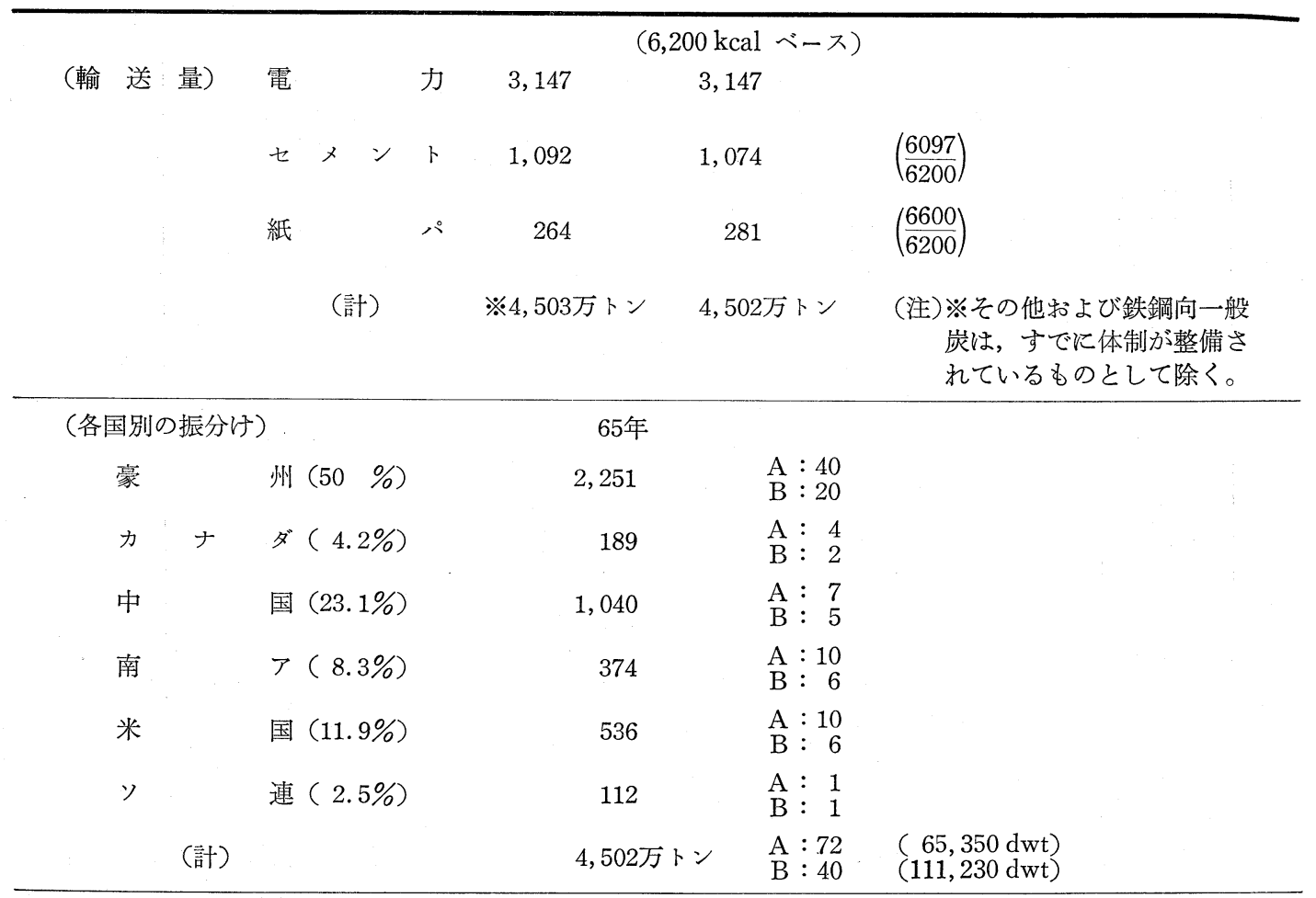

（投資 コスト）

65 年度 $72 \times 38,441 \mathrm{G} / \mathrm{T} \times 156$ 千円 $=4,318$ 億円

$40 \times 61,453 \mathrm{G} / \mathrm{T} \times 120$ 千円 $=2,950$ 億円

（80\%積取比の場合）

$$
\begin{aligned}
& 4,318 \text { 億 } \times 0.8=3,454 \text { 億円 } \\
& 2,950 \text { 億 } \times 0.8=2,360 \text { 億円 }
\end{aligned}
$$

（50\%積取比の場合）

ルセンターを選抜して，政府が融資などの面で強力な 支援を行らことにより，十分採算の取れるコールセン ターを何力所か建設する必要がある。また, 前述の中 継基地取扱必要量 2,442 万トンに見合らコールセンタ 一を建設するためには, 約 2,700 億円と石炭専用船の 建造量に近い水準の投資額を要し, 資金面に和ける政 府の助成策強化の必要性は高い。特に, 電力を除く一 般企業向けの融資の金利が5.95\%であるのに対して, 電力向けの融資の金利は $8.5 \%$ と別建の制度となって いる点が問題であり，この場合電力向けの石炭取扱い がベースとなるコールセンター建設に際しては高い金 利での融資を受けざるを得ず，電力を除く一般企業向
けのコールセンターの建設に比べ金利面で著しく不利 である。従って, コールセンターの建設を円滑に進め るためには, 是非共この別建の制度を一本化し, 電力 も一般企業と同様低い金利で融資が受けられるよらに すべきであると考えられる。

なお，コールセンターは，前述のよらな中継基地と しての機能の面だけでなく，ストライキ，天災などの ため石炭の供給が中断した場合に備える備蓄機能とい ら点からも評価されるようになって来て拉り, コール センター建設に対する潜在的需要ないし必要性は, 中 継取扱量以上に大きいものがあると思われる。従っ て, 政府によるコールセンター建設に対する助成策 
表 18 65年度迄に必要な中継基地取扱量と投資額

(電 力) ……1 単位 (発電所規模) が 150 万 $\mathrm{kW}$ を超えるものを省く $\cdots \cdots \cdots$ 約 300 万 $\mathrm{t}$

\begin{tabular}{|c|c|c|c|c|}
\hline 北 海 & 道 & $\begin{array}{l}\text { 苫東厚真 } 2(60) \\
\text { 未定分 }(45 \div 60) \times 0.5 \times 2.01\end{array}$ & $\begin{array}{l}121 \text { 万 } t \\
106 \text { 万 } t\end{array}$ & \\
\hline 東 & 北 & 能 代 $1.2(60 \times 2)$ & 161 & \\
\hline & 部 & 未定分 $(60 \times 2) \times 0.5 \times 2.01$ & 121 & \\
\hline & 国 & $\begin{array}{l}\text { 三 隅 } 1.2(70 \times 2) \\
\text { 新小野田 }(50 \times 2) \times 0.5 \times 2.01\end{array}$ & $\begin{array}{l}282 \\
101\end{array}$ & \\
\hline 力 & 州 & 松 $\quad$ 浦 $1(70)$ & $\begin{array}{r}141 \\
70\end{array}$ & \\
\hline 集友共 & 炎 & $\begin{array}{l}\text { 苓 北 } 1.2 \\
(16+18) \times 0.5 \times 2.01\end{array}$ & $\begin{array}{r}281 \\
34\end{array}$ & \\
\hline $\begin{array}{l}\text { 混焼率ア" } \\
\text { 転 換 期 }\end{array}$ & 兴 > $\left.^{\circ}\right\}$ & & 477 & \\
\hline & 合 & 計 & 1,895 万 $\mathrm{t}$ & \\
\hline （業＼cjkstart界 & 別） & 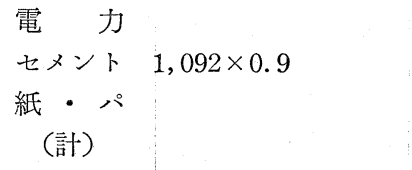 & $\begin{array}{l}1,895 \\
983 \\
264 \\
3,142 \text { 万 } \mathrm{t}\end{array}$ & \\
\hline $\begin{array}{l}142 \text { 万 } t \\
142 \text { 万 } t\end{array}$ & $\begin{array}{l}\times @ 11 \\
-(700 \\
11,000\end{array}$ & $\begin{array}{l}0 \text { 円 } / \mathrm{t} *=3,456 \text { 億 } \\
\begin{array}{l}\text { 現有設備 })=2,442 \text { 万 } \mathrm{t} \\
\mathrm{t} \quad=2,686 \text { 億円 }\end{array}\end{array}$ & & $\begin{array}{l}\text { 注 } * \text { 苫東厚真技よび崎戸ュー } \\
\text { ルセンターへの短期計画の建 } \\
\text { 設単価の平均 }\end{array}$ \\
\hline
\end{tabular}

\section{表 20 65年度迄に必要な内航船舶と投資額}

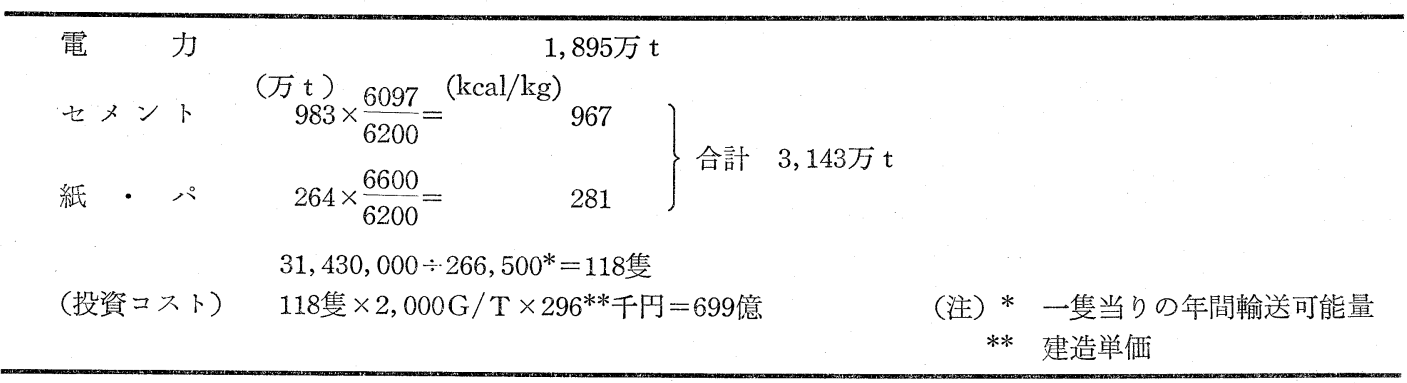

は，陸上設備に対する融資，港潪建設に対する補助金 供与という現在の制度以上に強化拡充することが，石 岸の利用拡大にとって不可欠の重要性を持っていると 言兄よう。

\subsection{3 内航船舶}

65年度迄に必要な内 航船舶は, 表20に示すように 118隻であり，その建造のために必要な投資額は699億 円である。しかし, 現在の内航船腹需給は, 表 21 貨 物船の欄に見られるように船腹過剩の状沉にあり，ス
クラップの代替としてしか内航船船の建造は認められ ていない。癷が、これにはかなりの問題があるものと 考学られる。すなわち, 海運造船合理化審議会の見通 しによると, 現在の船腹過剩る57年度には解消し，現 有船腹量のまむでは船腹不足となるため, 輸入炭の増 加に伴って新規に必要となる内航船舶 118 隻は, 今後 新たに建造する必要があるからである。従って，118 隻の内航船舶を順調に建造していくためには, 中小船 主が多いだけに資金面での助成も必要となるかる知孔 
表 19 コールセンター建設

\begin{tabular}{|c|c|c|c|c|c|}
\hline 地 域 & $\begin{array}{l}\text { 名称变たは点 } \\
\text { 地 }\end{array}$ & 計 画 主 体 & 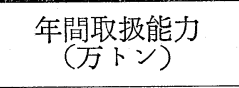 & $\begin{array}{l}\text { 完 成 予 定 } \\
\text { (昭和年/月) }\end{array}$ & ヤード面積 \\
\hline 九 州 & 崎＜wide>戸 & 石炭資源開発，九電 & 700 & 63 /春頃 & $?$ \\
\hline \multirow[b]{2}{*}{$" 1$} & \multirow{2}{*}{ 三 井 響 灘 } & \multirow{2}{*}{ 三井鉱山, 三井物産 } & $150 \sim 200$ & $56 / 9$ & 5 万 $\mathrm{m}^{2}$ \\
\hline & & & 700 & $60 / ?$ & 50 万 $\mathrm{m}^{2}$ \\
\hline 中 国 & 宇部・沖ノ山 & 宇 部 興 産 & $\begin{array}{l}\text { 当初 } 100 \\
\text { 最終 } 400 \sim 600\end{array}$ & $\begin{array}{l}56 / ? \\
57 / ? \\
58 \sim\end{array}$ & $\begin{array}{l}\text { 沖八山第 } 1 \\
100 \text { 个ン相当 } \\
\text { "1 第 } 2 \\
\text { 西沖 } \\
200 \text { 万トン相当 }\end{array}$ \\
\hline " & $\mathrm{NK} \quad \mathrm{C}, \mathrm{C}$ & 日 本 鋼 管 & 130 & （稼 働 中） & 7.5 万 $\mathrm{m}^{2}$ \\
\hline 近 畿 & 大 阪 北 港 & 大阪北港埠頭 & 30 & $(" \prime)$ & 2.2 万 $\mathrm{m}^{2}$ \\
\hline " & 敦 賀 & 敦賀海 陸 運 輸 & 25 & $(" \prime)$ & 4 万トン貯炭可能 \\
\hline 東 海 & 四 日市 & 四日市港管 理 組 合 & $\begin{array}{lr}\text { 当初 } 60 \\
\text { 終 } 100 \\
\end{array}$ & $56 / ? ?$ & $\begin{array}{c}6 \text { 万 } \mathrm{m}^{2} \\
?\end{array}$ \\
\hline 関 東 & 東洋埠頭(京浜) & 東 洋 埠 頭 & 120 & (稼 働 中) & $\begin{array}{l}\text { (川崎) } 3 \text { 万 } \mathrm{m}^{2} \\
\text { (豊州) } 5 \text { 万” }\end{array}$ \\
\hline$"$ & 三井埠頭 ( " ) & 三 井 埠 頭 & 現在 55(拡大中) & $(" \prime)$ & 現在 2 万 $\mathrm{m}^{2}$ \\
\hline 東 北 & 小 名 浜 & 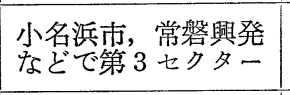 & $400 \sim 500$ & (バース完成) & 20 万 $\mathrm{m}^{2}$ \\
\hline 北海道 & 苫 小牧 東 & 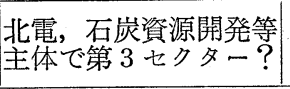 & $\begin{array}{ll}\text { 当初 } & 350 \\
\text { 終 } & 850 \sim 1,000\end{array}$ & $59 / 3$ & $?$ \\
\hline " & 室＼cjkstart蘭(祝津) & 室 & 100 & 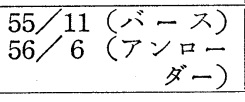 & 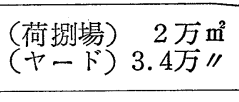 \\
\hline
\end{tabular}

[完成期など不明確，構想のみが伝宇られているもの]

\begin{tabular}{|c|c|c|c|c|c|}
\hline 九 州 & 伊 & 島 & 日 鉄 鉱 業 & $300 \sim 400$ & 30 万 $\mathrm{m}^{2}$ \\
\hline 四 国 & 新 & 浜 & 住友石炭鉱業 & 30 & 2.2 万 $\mathrm{m}^{2}$ \\
\hline " & 宿 & 毛 & 伊 藤 忠 & & \\
\hline 東 海 & 田 子 ノ & 浦 & & & \\
\hline
\end{tabular}

ないが，少なくともスクラップの代替としてしか新造 船の建造が認められない現行の新造船建造のルールは 見直す必要があうう。

\subsection{4 とめ}

以上のように石炭の輸送体制を整備するためには， 今後取組まねばならない問題点と課題は数多くめり,
その解決に当ってはあくまでも民間企業が主体となっ て努力すべきであるが，政府がこうした民間企業の自 助努力を側面から支援し, 輸送体制の整備が円滑飞進 むようにすることが, 山元から需要家迄の石炭の流 れ，所謂コールチェーンの確立と一般炭の利用拡大の ためには不可欠の重要性を持っている。表22に示すよ 
計画・構想一覧表

\begin{tabular}{|c|c|c|}
\hline バース能力など & 主要ユーザー & 備 \\
\hline$?$ & $\begin{array}{l}\text { 九電苓北 }(70 \mathrm{~kW} \times 2) \text { のほか } \\
\text { 同松浦など }\end{array}$ & $\begin{array}{l}\text { 三菱崎戸鉱業所跡地 } \\
\text { (年間取扱能力は } 400 \text { 万 説も) }\end{array}$ \\
\hline 水深 $13 \mathrm{~m}$ & 北九州地区セメント各社など & $\begin{array}{l}\text { 三井鉱山コークスの貯炭場の } \\
\text { 二部を利用 }\end{array}$ \\
\hline$?$ & 上記の注か九電なども & $\begin{array}{l}\text { 現在北九州市が造成中の埋立 } \\
\text { 地の一部に建設 }\end{array}$ \\
\hline$\left\{\begin{array}{c}\text { \#6バース } \\
3 \sim 4.5 \text { 万トン級 } \\
\\
?\end{array}\right.$ & $\begin{array}{l}\text { 自社用のほか旭化成（延岡） } \\
\text { 小野田セメント(小野田)，住 } \\
\text { 友共電近傍中小工場など }\end{array}$ & 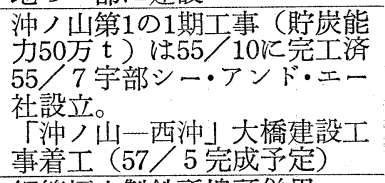 \\
\hline $7 \sim 20$ 万DWT & $\begin{array}{l}\text { 近秚セメント各社, 中国電力, } \\
\text { 住電か }\end{array}$ & 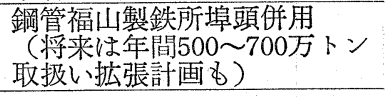 \\
\hline 2.5 万WT & 住友セメ，住金鉱山ほか & $\begin{array}{l}\text { 住友商事が関連会社への輸入 } \\
\text { 基地として利用 }\end{array}$ \\
\hline $\begin{array}{l}\mathrm{MAX} \\
1.2 \text { 万WT }\end{array}$ & $\begin{array}{l}\text { 大阪セメント，住友セメント } \\
\text { など }\end{array}$ & ソ連炭, 中国炭主体の基地 \\
\hline $\begin{array}{cc}\text { 水深 } & 12 \mathrm{~m} \\
\text { / } & 14 \mathrm{~m}\end{array}$ & $\begin{array}{l}\text { 小野田セメント(藤原), 住友 } \\
\text { セメント(岐阜)など }\end{array}$ & $\begin{array}{l}\text { 同港南埠頭に増設中の外貿岸 } \\
\text { 壁に石炭荷役施設, 貯炭場等 } \\
\text { を設置してC.C.とすする。 }\end{array}$ \\
\hline $\begin{array}{l}6 \text { 万 DWT } \\
\text { (水深 } 12 \mathrm{~m}) \\
1.5 \text { 万 } \\
(" \prime 10 \mathrm{~m})\end{array}$ & $\begin{array}{l}\text { 秩父セメント，三菱セメント } \\
\text { など }\end{array}$ & \\
\hline 3.7 万WT & 日セメなど & \\
\hline 5 万 DWT & 常磐共同火力など & \\
\hline$?$ & $\begin{array}{l}\text { 北電・苫東厚真 } 2 \text { 号機 }(60 \text { 万 } \\
\mathrm{kW}=59 / 9 \text { ) およひ後 } \\
\text { の増設分なぞ }\end{array}$ & \\
\hline $\begin{array}{l}5 \text { 万 DWT } \\
\text { (水深 } 12 \mathrm{~m} \text { ) }\end{array}$ & $\begin{array}{l}\text { 道内セメント，紙パなどが狙 } \\
\text { W }\end{array}$ & $\begin{array}{r}\text { 建設費12-3 億円 } \\
\text { （55年起債認可完） }\end{array}$ \\
\hline
\end{tabular}

\begin{tabular}{l|l|l}
\hline $\begin{array}{l}\text { 10万DWT } \\
7 \text { 万DWT }\end{array}$ & 住友共電, 住友セメントなど & $\begin{array}{l}\text { 日鉄鋼業炭礦跡地 } \\
\text { 住友アルミミベース利用 } \\
\text { 土地取得済? }\end{array}$ \\
\hline
\end{tabular}

(出所)「セキツウ」55年 12月 10 日号
らに, 一般炭の輸送体制の整備のためには 6,000 8,000 億円の投資額を要する。この投資額は，コール チェーン全体の完成のための所要投資額の $16 \sim 17 \%$ （表13 および表14より算出）に止をるとは言え，輸送 費が石炭の CIF 価格の50\%以上を占めるという事実 から見て, 輸送体制を整備することの重要性は大き
い。従って,コールチェーンの要とも言うべき輸送体 制の整備のために官民の関係者が積極的に努力し，一 般炭の利用拡大を推進することが, 日本経済の安定成 長の達成のためにも当面最も重要な課題と言うべきで めろら。 


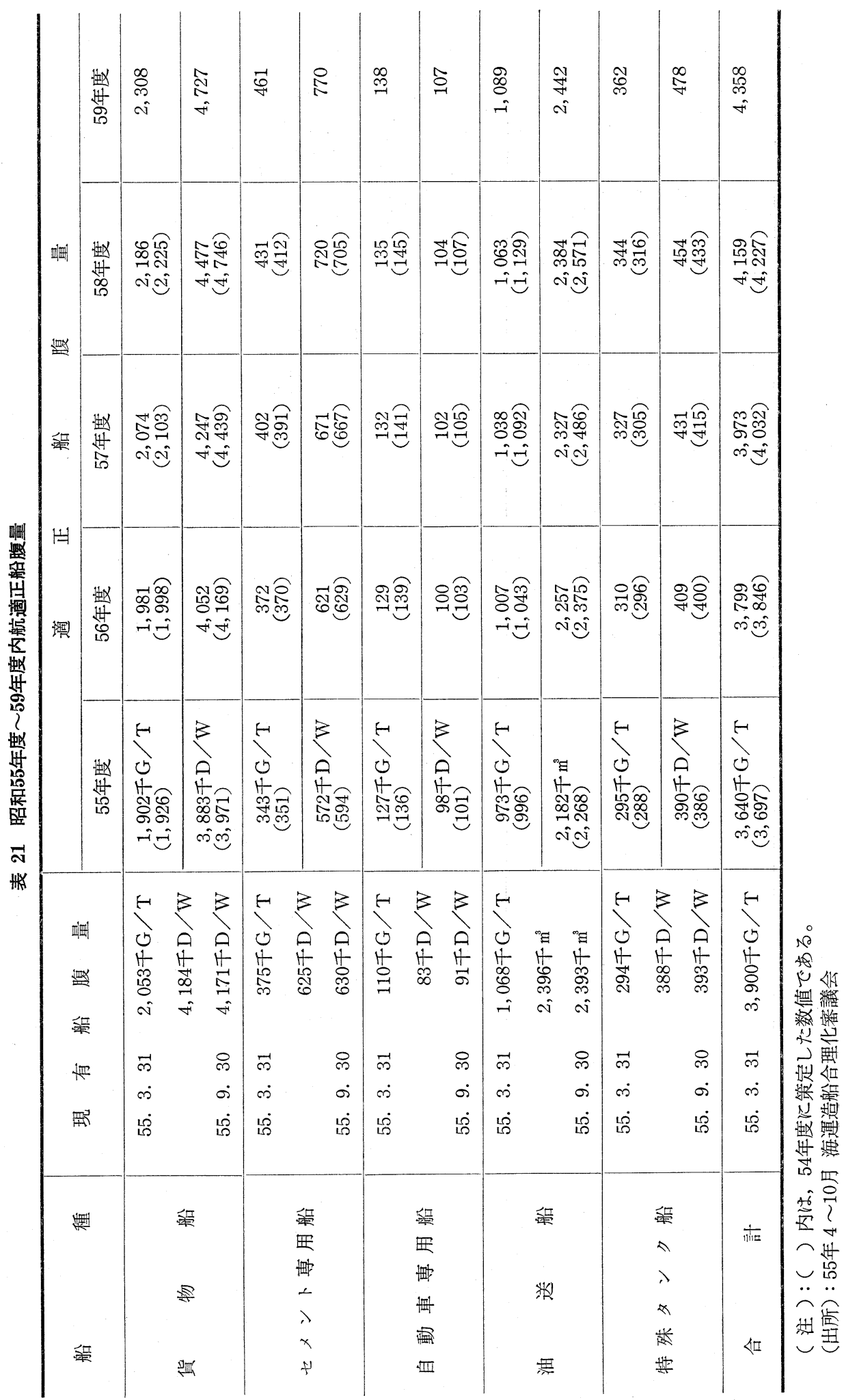


海上輸送輸送量 必要隻数 投 資 額

中継 基地取扱量 投 資 額

二次輸送輸送量 必要隻数 投 資 額

4,502 万 $\mathrm{t}$

Aケース 72隻

Aケース

72 隻

4, 318億円

Bケース 40隻

$3,454 \quad)$

Bケース

2,950 億円

$2,360 \quad$ )

合計投資額
$\mathrm{A} ケ-ス$
6, 839〜7, 703億円 $(65,350 \mathrm{dwt})$
$\mathrm{B}$ ケース
$5,745 \sim 6,335$
$(111,230 \mathrm{dwt})$

2,442 万 $\mathrm{t}$ （内，既存700万 $\mathrm{t}$ ）

2, 686億円

3, 143万 $\mathrm{t}$

118隻

699億円

（注）*(）内は積取比率80\%のケース

\title{
The Outlook for the Expanded Use of Steam Coal and the Establishment of Coal Chains
}

\author{
Akira CHIMurA \\ (Senior Economist, The Institute of Energy Economics)
}

SYNOPSIS :-

1. The Outlook for the Expanded Use of Steam Coal

1) The strong demand for steam coal exists now and will continue to exist in 1980's. Its import requirements are expected to increase to 20 million tons in F.Y. 1985 and 47 million tons in F.Y. 1990.

2) However, many steam coal consumers are facing the difficulties in obtaining the required steam coal supply, under the tight conditions of steam coal supply \& demand which are expected to continue for some coming years.

2. The Establishment of Coal Chains

1) The establishment of coal chains from coal mines to steam coal consumers is urgently needed, in order to meet the sharp increase of steam coal demand.

2) We should make a great effort to expand the production and shipping capacities in coal producing countries and to complete the transportation system such as sea-going and coastal ships and coal centers in Japan. 